\title{
Experimental studies as tools for solving practical problems of electromechanical nature
}

\author{
N. Nestoruk, P. Chykunov
}

Industrial Institute of Donetsk National Technical University, Pokrovsk, Ukraine,

Educational scientific professional pedagogical Institute of Ukrainian Engineering Pedagogics Academy, Bakhmut, Ukraine

Corresponding author. E-mail: natasha.nestoruk@yandex.ua; pashurka1975@gmail.com

Paper received 06.11.17; Revised 12.11.17; Accepted for publication 14.11.17.

https://doi.org/10.31174/SEND-NT2017-148V16-21

\begin{abstract}
The essence of experimental studies is clarified, notions of "experimental research" and "engineering experimentation" are identified, targets, content and technological components of the training of future mining engineers in the context of a tedious problem in accordance with the personality-oriented educational paradigm. Based on the analysis of the future specialist's activities, in accordance with the competence complex, has been developed a technology for the training of mining engineers and electromechanics for conducting experimental studies, and it is possible to improve the professional training of the future specialist.
\end{abstract}

Keywords: experimental research, engineering experimentation, competent oriented basis, technical disciplines, electromechanical engineers.

Introduction. Experimental research is one of the production functions of an engineer, which is caused by the need to organize tests of prototypes or creating of original models, research of structural materials, etc.

Study of the practice of future mining engineerselectromechanics training for experimental research in the context of sociocultural conditions for the development of society, links between experimental activities in the competence development of specialists in the electromechanical profile made it possible to realize the importance of the problem being studied for vocational training, which should provide not only an adequate level of theoretical knowledge, but also sufficient experience of experimental activity in the engineering sphere - that area, in which a professional is going to work [1].

If we talk about engineering experimentation in the professional electromechanics activity, we should first of all take into account the studies of meaningful interpretation of a theory of planning, organization and conducting of an experiment in an electric drive, which were implemented, in particular B. Ivobotenko, M. Ilyinsky, I. Kopylov, V. Klyuchev, B. Firago, L. Pavlyavchik, and also the work of A. Goldberg, which proposed a technique for electrical machines testing. Undoubted value of the last work are the block diagrams developed by the author, on which algorithmization of machines' industrial tests can be carried out and which can serve as a basis for designing the experimental activity of students in the process of mastering the content of technical disciplines.

Adjustment of electric drive control systems, which can be a stage of engineering experiment, is developed and described only in the reference literature, despite the fact that the control system of electric drives is the subject of study in the training systems not only of electromechanics, but also of other specialists.

Since the reference literature is a special edition, which, among other things, is characterized by a laconic and declarative statement of the setup stages, its application in the process of forming knowledge on tuning the electric drive at the algorithmic stage of preparing future specialists for an engineering experiment has certain features that require a methodical compilation. In particular, the directories don't contain a detailed exposition of the theoretical information, which is necessary to understand the semantic essence of the stages and individual actions. Also, they often lag behind the constructive and elemental base of practical control systems for electric machines.

From what has been said, it follows that it is necessary to master the technology of carrying out an engineering experiment, requires justification and definition of the relevant professional qualities, including professional skills. Thus, we have established that the specific weight and cognitive quality of experimental studies that can start in the study of technical disciplines, make it necessary to determine the proper organizational, managerial and methodical measures and means of influencing the course and results of training in order to master future mining electromechanical engineers' professional abilities that are necessary for experimental work. This would make it possible to provide them with the ability to engineer experimentation and readiness to apply it in the further professional work in production.

Brief overview of related publications. With the experimental activities in the training programs of electromechanical profile involves a significant number of works from different research areas and levels, from program articles to dissertation studies and tutorials $[2 ; 3 ; 4 ; 5 ; 6]$ etc. But despite their different aspects and depth of study, the matter of the experimental research mastering by the electromechanical engineers during the process of technical subjects studying, in our opinion, is not perfect and comprehensive.

The purpose of this article was to determine the adequacy of the formulated theoretical provisions and the effectiveness of the justified on their basis technology of professionally significant skills formation for the electromechanical profile students to the experimental research.

Materials and methods. To achieve the goal, a set of complementary scientific methods, reflecting the dialectical unity of the theoretical and empirical levels of cognition:

- theoretical - analysis of educational normative sources, psychological, pedagogical, methodological and special literature, dissertation materials, professional publications with the aim of generalization, systematization, comparison and comparison of different views on research;

- empirical - pedagogical observation to determine the dynamics of change.

In engineering, as in many others activities, one of the methods of cognition is engineering experience. It is used in the design and development work, in the experimental 
and experimental stages of the development of new technology and etc. At the same time, engineering experience is applied limitedly in the process of technological or operational activities, and it is widely used in experimental studies conducting.

Limited application of the experiment in operational activities is due to the fact that the latter is oriented to servicing, industrial systems repair, as well as transporting, storing, preparing for the intended use (in particular installation, testing and commissioning) of production equipment. Operation involves monitoring the operation of equipment in order to ensure the optimal mode of its operation, control its operation.

In the professional activity of specialists in the electromechanical profile, an important role is assigned to several areas that determine the subject-activity complex, which is formed by organizational and managerial and engineering-technical activities that cover the social and professional spheres of being a specialist [7].

Organizational and managerial activity of engineering employees provides systematic and purposeful leadership of the team in the production process.

Engineering and technical activity provides preparation of production, direct production, as well as maintenance of production facilities in the course of practical training. Engineering and technical activities have following components: design, technology, research, operational.

The design component of the specialists' activity of the electromechanical profile in practical terms is guided by the development of new technology, refinement, modernization of the existing one. Results of the design activities are presented in the form of technical documentation designed to organize the production and operation of new equipment or the modernization of the existing one.

Technological component of the specialist's activity of the electromechanical profile ensuring compliance with the design parameters of those production processes in which future specialists participate in the acquisition of practical experience and skills in performing technological operations, notes V. V. Borisov [8, p. 20-21].

Research component of the specialist's activity of the electromechanical profile is directed to obtaining new scientific knowledge, clarifying and generalizing the already available ones. In the process of such activities, scientific assumptions are confirmed or disproved, new ways of known problems' solving are searched, etc., which, in our opinion, is an important element in the formation of the competence basis for the future specialist, his readiness for practical activities.

Depending on which methods (theoretical or empirical) prevail in the study, individual steps that are listed above can become irrelevant and not be included in the research plan. But practically in any research a special place is given to the experiment.

If we talk about the modern definition of this concept, then we can use several approaches presented by L. M. Cherchik:

«An experiment is the testing of knowledge of the phenomena under study in controlled or artificially created conditions. ...

An experiment is a system of operations, influence or observations aimed at obtaining information about an object during research trials that can be conducted under natural and artificial conditions when the nature of the process is changed.

An experiment is a way of investigating phenomena and processes through the organization of special experiments that ensure the study of the influence of individual factors under the constancy of other conditions or the modeling of phenomena and processes in practice» $[9, \mathrm{p}$. 8].

Triplicity of the author's interpretation is explained by the factor of origin in the experimental activity, that is, the need to clarify the question of the purpose of the experiment: either we want to check something, or determine the system of operations, it allows us to achieve certain information results, or to study the influence of what factors on the phenomenon being studied.

Since the experiment is usually a stage in a study in which, using certain empirical methods, some results are obtained, that are included in the so-called empirical research cycle, then in the future we can call this stage in the projection for educational activity experimental research and think of it as about a cyclic process in which several mental acts (steps) are used, successively replacing each other and interpolating the researcher closer to the informative result, on the basis of which it will be possible to formulate conclusions and propose recommendations on the possible introduction of the obtained results into production or intellectual activity.

If we talk about experimental studies from didactic positions in the projection of mastering the content of technical disciplines, then it is expedient to take as a basis the following interpretation, which we accepted in the collective (S. F. Artyukh, I. Ya. Lizan, I. V. Goloperov, N. A. Nestoruk) in the training manual "Fundamentals of Scientific Research" [2, p. 90].

Experimental studies are studies based on an experiment, which is based on scientific experience or observing a phenomenon under given conditions and allows you to monitor its progress, control it, obtain the necessary data and restore it when the initial conditions are repeated.

Since there is a significant list of technical disciplines in the system of training specialists in the electromechanical profile ("Theory of electric drive", "Electric machines", "Elements of automated electric drive", "Theory of automatic control", etc.) and their training programs envisaged to apply not only theoretical but also empirical methods of acquiring knowledge, then experimental research in the study of these disciplines should be an integral part of learning.

"The subject of the technical disciplines study are real objects of practice - mechanisms, devices, machines, means of their construction, the effectiveness of their functioning, etc. These disciplines examine large classes of homogeneous objects (technical devices and machines of a certain class) and look for a correlation and transformations that make it possible to reduce complex and cumbersome tasks and calculations to simple ones. At the same time, theoretical knowledge is not separated from practice one (as in natural sciences), but combined with it" [10, p. 52].

Experimental research in the professional activity of electrical engineers begins to form the professional competencies (qualities) of the specialist, active management of the cognitive process associated with the analysis of 
the qualitative and quantitative characteristics of those objects, properties, qualities, characteristics, magnitudes, etc., are investigated in the experiment. Specificity of experimental studies in the activity of electromechanics is the fact they are carried out for:

- theoretical obtaining of analytic dependence, which uniquely and exhaustively characterizes the investigation process;

- establishment of the dependence by theoretical means (which leads to an increase in the scope of the experiment);

- implementation of search activities to establish dependencies, which could not be obtained theoretically [2, p. 49-50].

We have found that the skills requirements for the electromechanical profile students, determining the content of their educational courses, lead to the forming of abilities to the engineering experimentation, namely to:

- analyzing experimental studies of the electromechanical devices;

- planning a pilot study;

- assembling of schemes of the electromechanical devices;

- adjusting the electromechanical devices;

- carrying out tests or experiments;

- performing statistical processing of experimental data and mathematical modeling of the electromechanical phenomena and processes;

- making conclusions and generalizations of the research results.

According to our task we have designed a model of the professionally significant skills formation of the future electromechanical engineers in carrying out the experimental research while mastering the content of the technical disciplines [11, c. 36-42].

The content of the technical disciplines providing experimental research is oriented in the channel of the developed technology for the formatting in the future electromechanical engineers the professionally significant skills that are the basis of the research competence.

In the process of preparing specialists for conducting experimental research while mastering the content of technical disciplines, in addition to practical exercises, they take laboratory work, since they provide the opportunity to directly simulate situations in which the engineering experiment is the main means of obtaining information for decision-making, and also provide a source of practical experience for experimental activities. Learning objectives may include various ways of performing, depending on the available tools, data processing facilities, and etc.

Based on this, we can assume that the involvement of mining engineers of electromechanical specialties in experimental activities must occur under certain conditions, among which the most important are its proper material and technical and methodological support; step-by-step planning; creation of a single educational and methodical environment; presence of a set of relevant academic dis- ciplines; providing favorable motivational support. But the main pedagogical condition that ensures the implementation of a competently oriented teaching technology is use of such didactic principles as: determinism, systematicity, differentiation, variability, integrativity and interactive learning.

Results and discussion. The main provisions and results of the research were made public at scientific and practical conferences, in particular:

- International: "Problems of modern energy and automatics in the system of natural resources use" (Kyiv, 2016), "Innovative development of the mining industry" (Kryvy Rih, 2016), "Higher school in the context of European integration processes" (Cherkasy, 2017), "Current trends in the development of education, science and technology" (Bakhmut, 2017);

- All-Ukrainian: "Modern aspects of mechanization and automation of energy-intensive industries" (Pokrovsk, 2017), "Computer technologies in power engineering, electromechanics and control systems" (Bakhmut, 2017);

- Regional: "Problems of Mining Technology" (Pokrovsk, 2016).

The projected technology of training future engineerselectromechanics to experimental studies has been approved and may be extended to other higher and vocational schools and technical colleges.

Conclusions. Based on the practice study of mining engineers students of the electromechanical profile training, it has been established that experimental studies in the process of studying professionally oriented (technical) disciplines of electromechanical specialties have a leading role in forming a set of competencies in the future specialists sufficient for professional activity in conditions of a real production or training process and it is reasoned that the competence requirements for future engineerselectromechanics in the formation of them capable of those to professional activities that determine the content of student training.

It was found out that the preparation of future mining engineers for experimental research activities must occur under certain conditions, among which the most important are its proper material and technical and methodological support; step-by-step planning; creation of a single educational and methodical environment; presence of a set of relevant academic disciplines; providing favorable motivational support. But the main pedagogical condition that ensures the implementation of a competently oriented teaching methodology is use of such didactic principles as: determinism, systematicity, differentiation, variability, integrativity and interactive learning.

It is emphasized that the content of technical disciplines, which involves conducting experimental research, is oriented on the formation of professionally significant skills by future electromechanics, which are the basis of research competence, which are in the category of demanded in the future professional activity and are tools for solving practical tasks of electromechanical nature.

\section{REFERENCES}

1. Nestoruk N. A. Experimental studies in the context of competence electromechanical teacher's engineers: [E. resource]/Natalia Anatolevna Nestoruk // Public education: Electronic scientific specialized edition. - 2013. - Release 
Ukr.).

3. Krokoshenko, O. (2010). The components of professionalpedagogical activity of an engineer-pedagogue in amodern system of professional education./The Messenger of Luhansk national University of Taras Shevchenko: Pedagogical Sciences series. Luhansk (in Ukr.).

4. Pyatnitskaya-Poznyakova, I. (2003). Fundamentals of scientific research in higher school: tutorial. Kyiv (in Ukr.).

5. Petruk, W. (2006). Theoretical-methodical bases of formation of professional competence of future specialists of technical specialties in the study of fundamental disciplines: Monograph (in Ukr.).

6. Erganova, N. (2007). The methodology of professional education: a tutorial for students of higher educational establishments. Moscow (in Russ.).

7. Zarubinskaya I. B. Formation of social competence of students of higher educational institutions (theoretical and methodological aspect): [Monograph]/Irina Borisovna Zarubinskaya. - K.: KNEU, 2010 - 348 p.
8. Borisov V. V. Use of design and engineering tasks in the lessons of labor training/Vyacheslav Viktorovich Borisov // Newsletter of the Chernigov State Pedagogical University named after T. G. Shevchenko. - Release 93. - Series: Teaching Science/Head Editor M. O. Nosko. - Chernihiv: CNPU 2011. - № 93. -p. 19-22.

9. Cherchik L. M. Electronic manual on discipline "Research Methodology": [E. resource]/Larisa Nikolaevna Cherchik; Lutsk National Technical University. - Luck, 2012. - Access: http://lib.lntu.info/books/fb/pesp/2012/12-31/.

10. Gryzun L. E. Determination of the specifics of educational disciplines of various types as one of the factors forming the content of higher professional education/Lyudmila Eduardovna Gryzun // Pedagogy, psychology and medicobiological problems of physical education and sport: Science journal. -2008.-№ 8.- - p. 51-56.

11. Nestoruk, N. (2016). Conceptual aspects of engineering experiments of mining engineers-electromechanics/Problems of mining technology. Pokrovsk (in Ukr.). pp. 36-42.

\section{Экспериментальные исследования, как инструментарий решения практических задач электромеханического харак-} тера

Н. А. Несторук, П. А. Чикунов

Аннотация. Уточнена сущность экспериментальных исследований, где понятия «экспериментальные исследования» и «инженерное экспериментирования» отождествляются, уточнены целевые ориентиры, содержание и технологические составляющие подготовки будущих горных инженеров в контексте личностно-ориентированной парадигмы образования. На основе анализа деятельности будущего специалиста в соответствии с комплексом компетенций разработана технология подготовки горных инженеров-электромехаников к проведению экспериментальных исследований, которая позволяет усовершенствовать профессиональную подготовку будущего специалиста.

Ключевые слова: экспериментальные исследования, инженерное экспериментирование, компетентностноориентированный подход, технические дисциплины, инженеры-электромеханики.

Експериментальні дослідження, як інструментарій розв'язання практичних завдань електромеханічного характеру Н. А. Несторук, П. О. Чикунов

Анотація. Уточнено сутність експериментальних досліджень, де поняття «експериментальні дослідження» й «інженерне експериментування» ототожнюються, цільові орієнтири, змістові й технологічні складники підготовки майбутніх гірничих інженерів в контексті студійованої проблеми відповідно до особистісно-орієнтованої парадигми освіти. На основі аналізу діяльності майбутнього фахівця відповідно до комплексу компетентностей було розроблено технологію підготовки гірничих інженерів-електромеханіків до проведення експериментальних досліджень, що дозволяє удосконалити професійну підготовку майбутнього фахівця.

Ключові слова: експериментальні дослідження, інженерне експериментування, компетентісно-орієнтована основа, технічні дисиипліни, інженери-електромеханіки. 